\title{
Plasma levels and tissue expression of soluble TGF $\beta r$ Ill receptor in women with early-stage breast cancer and in healthy women: a prospective observational study
}

Lovorka Grgurevic ${ }^{1,2,5^{*}} \mathbb{D}$, Ruder Novak ${ }^{1}$, Vladimir Trkulja ${ }^{3}$, Stela Hrkac ${ }^{1}$, Grgur Salai ${ }^{1}$, Josko Bilandzic ${ }^{1}$, Lejla Ferhatovic Hamzic ${ }^{1}$, Ivan Milas ${ }^{4}$, Tiha Vucemilo ${ }^{4}$, Melita Peric Balja ${ }^{4}$ and Karmen Bilic ${ }^{4}$

\begin{abstract}
Background: Mammary carcinogenesis is partly regulated by the transforming growth factor beta (TGF $\beta$ ) signaling pathway. Its function in cancer progression and metastasis is highly dependent on disease stage, and it is likely modulated by the ratio of membrane-bound vs. soluble TGF $\beta$ rlll (sTGFßrllI). In this prospective observational study, we assessed tissue expression and plasma levels of sTGF $\beta$ rlll in healthy women, women with benign breast lesions and in early-stage breast cancer patients.

Methods: In a preliminary study, plasma sTGFßrlll levels were determined in 13 healthy women (age 19-40 years) at different phases of the ovarian cycle, and in 15 patients (age 35-75 years) at different times of the day. The main study assessed plasma concentrations of sTGF $\beta$ rlll in: (i) 158 healthy women in whom breast lesions were excluded; (ii) 65 women with benign breast lesions; (iii) 147 women with newly diagnosed breast cancer classified as American Joint Committee on Cancer (AJCC) stages 0 to IIB. Completers provided blood samples before surgery and at 10-30 and 160-180 days after surgery. Plasma sTGFBrlll concentrations were determined using an indirect ELISA kit. Part of the removed tissues underwent immunohistochemical (IHC) staining and analysis of tissue TGFBrlll expression.

Results: There appeared no relevant variations in plasma sTGFßrIll levels at different times of the day or different ovarian cycle phases. Before surgery, breast cancer patients had somewhat higher sTGFßrlll than healthy women, or those with benign breast lesions (by 14.5 and $26 \mathrm{ng} / \mathrm{mL}$, respectively), with a tendency of larger differences at higher age. This correlated with lower expression of TGF $\beta r l l l$ in breast cancer vs. healthy tissue samples. At 160-180 days after surgery, plasma sTGFßrlll levels in breast cancer patients declined by $23-26 \mathrm{ng} / \mathrm{mL}$.

Conclusions: Plasma sTGF $\beta$ rlll levels do not seem to relevantly vary during the day or the ovarian cycle. The coinciding higher plasma levels in newly diagnosed cancer patients than in healthy subjects and lower TGF $\beta$ rlll expression in the malignant than in healthy breast tissue suggest ectodomain shedding as a source of circulating STGF $\beta$ rlll. Decline in plasma levels after tumor removal supports such a view.
\end{abstract}

Keywords: Soluble TGFßrlll, Betaglycan, Breast cancer, Shedding

*Correspondence: lovorka.grgurevic@mef.hr

${ }^{5}$ Center for Proteomics, Center for Translational and Clinical Research, School of Medicine, University of Zagreb, Salata 11, Zagreb, Croatia

Full list of author information is available at the end of the article

\section{Background}

Breast neoplasms are the most common malignancies in women, and are the leading cause of cancer-related deaths in both developed and developing countries $[1,2]$. Dysfunctional regulation of hormonal signaling pathways

(c) The Author(s) 2020. This article is licensed under a Creative Commons Attribution 4.0 International License, which permits use, sharing, adaptation, distribution and reproduction in any medium or format, as long as you give appropriate credit to the original author(s) and the source, provide a link to the Creative Commons licence, and indicate if changes were made. The images or other third party material in this article are included in the article's Creative Commons licence, unless indicated otherwise in a credit line to the material. If material is not included in the article's Creative Commons licence and your intended use is not permitted by statutory regulation or exceeds the permitted use, you will need to obtain permission directly from the copyright holder. To view a copy of this licence, visit http://creativeco mmons.org/licenses/by/4.0/. The Creative Commons Public Domain Dedication waiver (http://creativecommons.org/publicdomain/ zero/1.0/) applies to the data made available in this article, unless otherwise stated in a credit line to the data. 
can drive cell proliferation and enable accumulation of genetic errors, which is important for initiation and progression of breast cancer. In recent years, there have been significant advances in breast cancer treatment, but timely diagnosis remains an important factor for patient survival. Several non-invasive procedures, like determining the expression levels of estrogen, progesterone and epidermal growth factor (EGF) receptors, are used for risk stratification and outcome prediction in breast cancer patients [3]. However, revealing the potential for metastatic changes is still largely based on clinical findings and radiologic examination, which often lack sensitivity, since they cannot detect micrometastatic disease. Detection of circulating tumor cells has recently been proposed as an independent early sign of breast cancer metastasis, but it lacks confirmation in prospective studies [4]. Neutrophil/lymphocyte ratio has also been investigated as a predictor of survival, although it has proven useful only in patients without metastatic disease [5].

Mammary carcinogenesis is partly regulated by the ubiquitous transforming growth factor beta (TGFß) signaling pathway, which is involved in a myriad of cellular functions, including development and homeostasis. The importance of preserved TGF $\beta$ signaling in cancer has been long recognized, since its loss, or even reduction, are correlated to poor disease prognosis [6]. However, its role in malignant transformation, tumor progression and metastasis is still poorly understood since it has a dichotomous function in different cancer types: although it can suppress tumorigenesis in early stages, it promotes tumor growth in late disease stages $[7,8]$. This balance is likely fine-tuned through the availability of the TGFß receptor type III (TGFßrIII, betaglycan), whose role is to present ligands to the TGF $\beta$ type I and II receptors, leading to increased signaling through the canonical TGF $\beta$ pathway $[6,9-11]$. This abundantly expressed co-receptor can act as a membrane bound, or a soluble effector. If its extracellular domain is released through ectodomain shedding, the soluble form of TGF $\beta$ rIII (sTGFßrIII) is produced and it can be detected in the extracellular matrix, serum and milk [12]. Its function appears to be preserved as it can effectively bind all isoforms of TGF $\beta$, bone morphogenetic proteins (BMPs), fibroblast growth factor (FGF) and inhibin $[7,9]$. This proteolytic cleavage of TGF $\beta r I I I$ is highly regulated by matrix metalloproteinases and disintegrin metalloproteinase (ADAM) molecules [11]. The release of TGFßrIII reduces its membrane expression and decreases TGF $\beta$ signaling, since it prevents ligand presentation to the membrane-bound TGF $\beta$ receptors [13]. In breast cancer animal models it was shown that the downregulation of TGF $\beta$ rIII/sTGF $\beta$ rIII effectively dampens the host antitumor immune response, thus promoting cancer progression [14]. Accordingly, treatment with exogenous sTGF $\beta$ rIII leads to an inhibition of tumor growth, metastasis and angiogenesis in breast cancer in vitro and in animal models $[13,14]$. These findings are in line with tumor and metastasis promoting nature of TGF- $\beta$ in the later stages of cancer progression [17].

Our previous smaller study [7], using an in-house developed polyclonal antibody, suggested lower plasma sTGF $\beta$ rIII concentrations in women with American Joint Committee on Cancer (AJCC) stage 0-IIB breast carcinoma than in their healthy peers, and a trend towards increasing levels over 2 months after surgery in diseased women. In the present larger study, using a standardized commercial enzyme linked immunosorbent assay (ELISA) detection kit, we aimed to assess plasma sTGFßrIII concentrations in healthy women, women with benign breast lesions and women with AJCC stage 0 -IIB breast cancer before surgical treatment and over a period of 6 months after surgery.

\section{Methods}

Study outline. This prospective observational study was approved by the Ethics Committee of the University Hospital Center Sestre milosrdnice (EP-1402/18-3). All participants provided a signed informed consent. All blood samples were centrifuged to obtain platelet poor plasma and stored at $-80{ }^{\circ} \mathrm{C}$ until analysis. In the preliminary part, plasma sTGF $\beta$ rIII levels were determined in a smaller group of healthy women at different phases of the ovarian cycle, and in a smaller group of breast cancer patients at different times of the day (Fig. 1). The main study assessed plasma sTGFßrIII concentrations in: (i) healthy women in whom breast lesions were excluded during preventive check-ups; (ii) women with benign breast lesions, as identified by biopsy; (iii) women with breast cancer classified as AJCC stage 0 to IIB. Breast cancer patients were sampled at three time points: 1-10 days before surgery, at $10-30$ and $160-180$ days after surgery (Fig. 1). Part of the removed tissue underwent immunohistochemical (IHC) staining for TGFßrIII (Fig. 1).

\section{Preliminary evaluations}

In order to evaluate the dependence of plasma sTGFßrIII levels on the menstrual cycle, 13 healthy women provided blood samples (between 09:00 and 11:00 a.m.) between days 2 and 8 of the ovarian cycle (follicular phase), between days 12 and 16 (mid-phase, peri-ovulatory) and between days 21 and 26-28 (luteal phase). To exclude the possibility of diurnal variation, 15 hospitalized women with diagnosed breast cancer (before treatment) provided blood samples at 10:00, 13:00 and 18:00 $\mathrm{h}$ on the same day. 


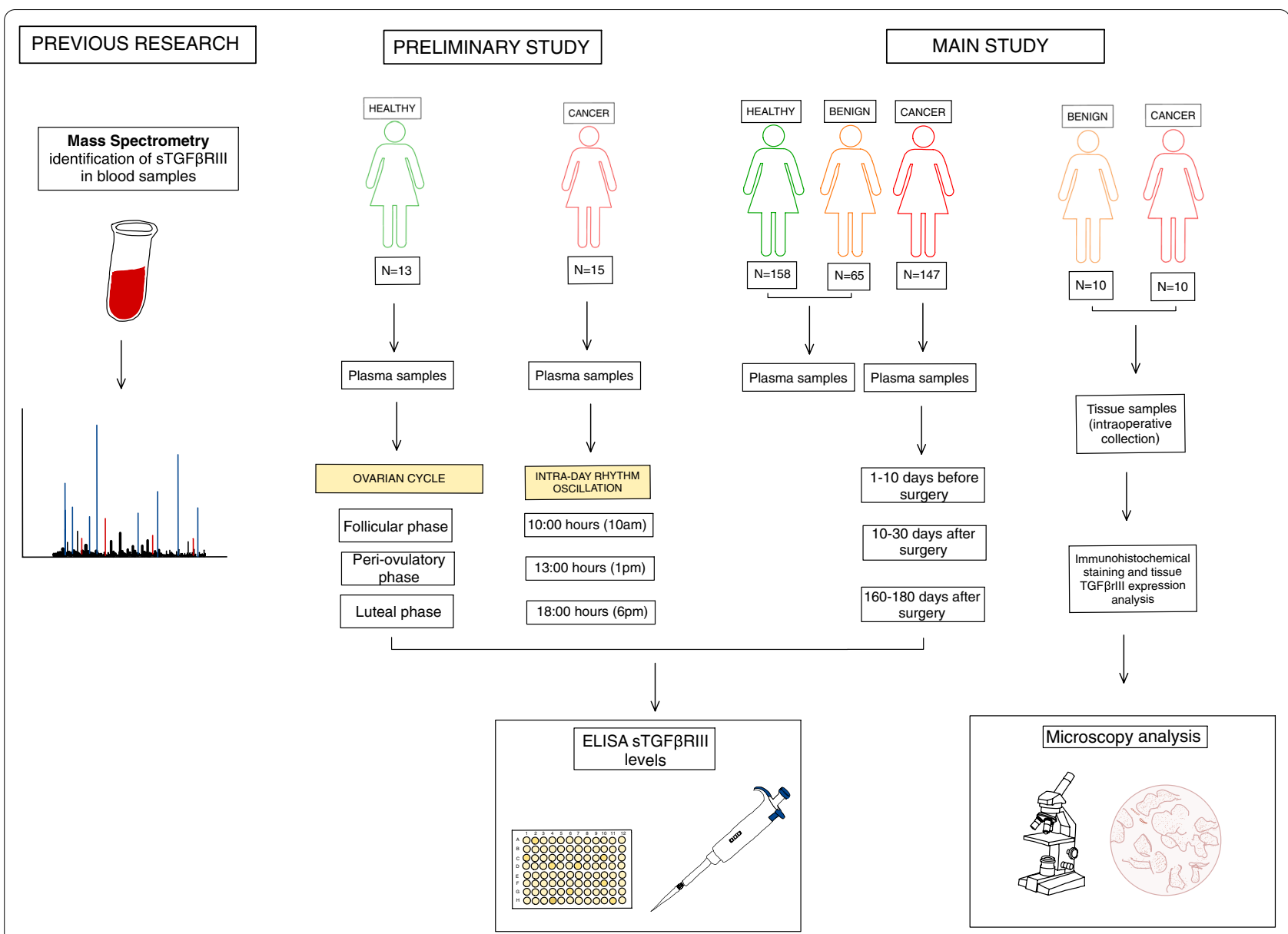

Fig. 1 A schematic depiction of the study outline, subject groups and sample time points

\section{Patient management}

A common inclusion criterion was signed informed consent. Women diagnosed with breast cancer ("cases") AJCC stage 0-IIB were surgically treated. Primary surgical procedures included: mastectomy (with or without primary reconstruction), breast-conserving surgery, sentinel lymph node biopsy, or axillary lymph node dissection. Indication for the type of primary surgery was determined by a multidisciplinary team depending on the size of the tumor, localization, its biology and the patient's preference. Therapeutic goals included complete resection of the primary tumor, with negative margins to reduce the risk of local recurrences, and pathologic staging of the tumor and axillary lymph nodes to provide necessary prognostic information. Based on patient's age and cardiovascular status, and in line with the tumor characteristics, adjuvant chemotherapeutic protocols were individually selected and commenced between the 4th and 6th postoperative week. Premenopausal women with hormone receptor-positive tumors were treated with tamoxifen, whereas postmenopausal women were treated with aromatase inhibitors. IHC was used to test for human epidermal growth factor receptor 2 (HER2)-positive tumors and borderline-significant specimens were further analyzed by the fluorescence in situ hybridization (FISH). Patients with HER2-positive tumors were treated with trastuzumab for one year. Locoregional irradiation was administered in women who met the radiation criteria. Patient follow-up included in this study occurred at two time points: $10-30$ days and 160-180 days after surgery, i.e. tumor mass removal.

\section{Detection of sTGFßrIII}

Blood samples for sTGFßrIII plasma measurements in the main part of the study were taken during a.m. All procedures and evaluation of the results were conducted by researchers blinded to clinical and pathological patient data. STGFßrIII in plasma was detected using an indirect ELISA kit (Human TGF-beta RIII DuoSet DY242, R\&D, Minneapolis, MN), according to manufacturer's instructions. Results were obtained with a plate reader (Molecular Devices-SpectraMax i3x) at $540 \mathrm{~nm}$. All samples and 
standards were analyzed in duplicates and samples with an individual coefficient of variation $(\mathrm{CV})$ greater than $25 \%$ were retested in duplicates. Tissue sTGF $\beta$ rIII expression levels in benign and malignant breast lesions $(\mathrm{N}=10$ randomly chosen samples per group) were determined on formalin-fixed paraffin-embedded tissue sections by IHC. Selected tissues were cut in 3-4 $\mu \mathrm{m}$ sections, mounted on slides, and dried at $60{ }^{\circ} \mathrm{C}$ for $60 \mathrm{~min}$. Dewaxing and target heat retrieval were performed simultaneously in automated PTLink (Dako) for $20 \mathrm{~min}$ at $97^{\circ} \mathrm{C}$ in Target retrieval solution (3 in 1), pH 9.0 (S2367; Dako, Glostrup, Denmark). After blocking peroxidase with $5 \%$ hydrogen peroxide for $5 \mathrm{~min}$, sections were incubated with a primary murine monoclonal antibody against TGF $\beta r I I I$, (clone A4, sc-74511, Santa Cruz Biotechnology, USA) at a dilution of 1:50, at room temperature for $60 \mathrm{~min}$. Thereafter, a secondary antibody conjugated to horseradish peroxidase (EnVision Flex/HRP high pH; Dako, Denmark) was applied for $50 \mathrm{~min}$. Finally, sections were incubated with 3,3'-diaminobenzidine chromogen, contrasted with hematoxylin, and cover-slipped. Benign lesions included fibroadenomas, tubular adenomas, adenosis, usual ductal hyperplasia, and mastitis. Malignant lesions included in situ and invasive cancers. Most invasive cancers were ductal invasive carcinoma (no special type) and one case was a lobular invasive cancer. Adenosis as a benign breast condition served as a positive control, whereas tissue sections stained with murine immunoglobulin G instead of a primary antibody served as a secondary antibody only control. Stained slides were analyzed using an optical microscope (Zeiss Axiostar plus, magnification range $20 \mathrm{X}$ and $40 \mathrm{X})$. IHC evaluation was performed by two investigators blinded to clinical and pathologic data (LG, GS) and reconfirmed by a second evaluation by a boardcertified pathologist (MPB) blinded to the interpretations of the first set of evaluations. Immunostaining results were compared, and discrepancies were reviewed. There was significant agreement between the three observers
(98\% correspondence); thus, the pathologist's scores are presented.

\section{Data analysis}

In preliminary evaluations, ln-transformed plasma sTGFßrIII concentrations were analyzed by fitting generalized linear mixed models with time (ovarian cycle phase or time of the day) and age as fixed effects. Plasma concentrations in healthy women, women with benign lesions and women with breast cancer before surgery were compared by fitting a generalized linear model with health status, age and health status*age interaction, and effects were expressed as adjusted mean differences. Plasma sTGFßrIII concentrations in women with breast cancer determined at different time points after surgery were compared to values before surgery by fitting generalized linear mixed models with time point, age, time point*age interaction and AJCC stage as fixed effects. All confidence intervals and P-values were adjusted for multiplicity by the simulation method. We used SAS for Windows 9.4 (SAS Inc., Cary, NC), procedure GLIMMIX.

\section{Results}

\section{Preliminary study}

Plasma sTGFßrIII expression levels appeared similar at different ovarian cycle phases in healthy women (geometric means ratios (GMRs), at mid- and luteal phase vs. follicular phase closely around 1.0; Fig. 2a) and at different times during the day in women with breast cancer (GMRs at 13:00 and 18:00 h vs. 10:00 h closely around 1.0; Fig. 2b).

\section{Plasma sTGFßrlll levels in women with breast cancer, benign lesions and in healthy women}

A total of 158 healthy women, 65 women with benign lesions and 147 women with AJCC stage 0-IIB breast cancer (13 stage 0 [carcinoma in situ], 47 stage IA, 33 stage IB, 45 stage IIA and 9 stage IIB) were enrolled in the
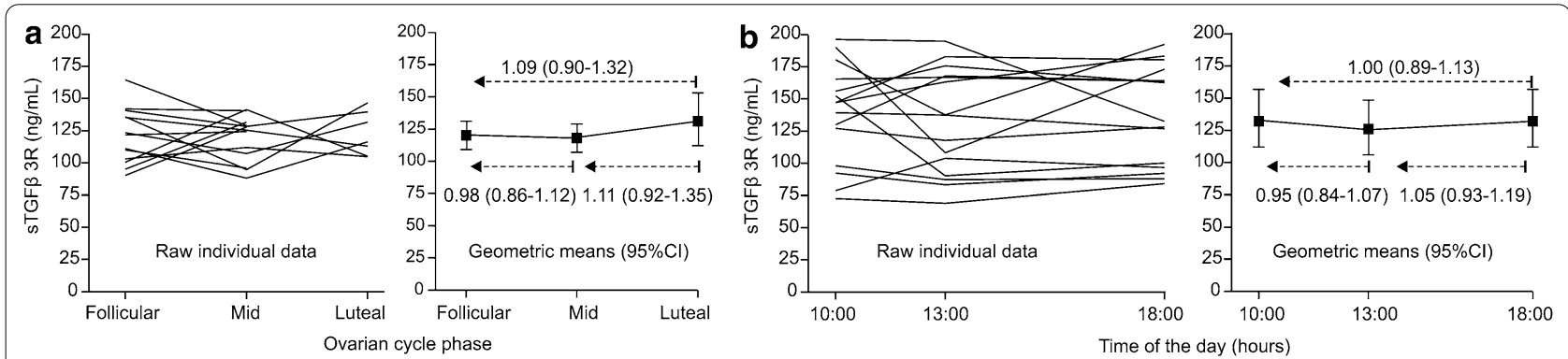

Fig. 2 Preliminary study. a Plasma sTGF $\beta r l l l$ expression levels at different parts of the ovarian cycle in 13 healthy women aged $19-40$ years. b Plasma sTGFßrlll expression levels at different times of the day in 15 hospitalized women with breast cancer AJCC stage 0-IIB (prior to surgery), aged 35-75 years 
main part of the study. On average, women with breast cancer were older and had somewhat higher sTGFßrIII plasma levels (similarly across tumor stages) taken before surgery than healthy women and women with benign breast lesions (Table 1). Figure 3a illustrates the "shift" in age and concentration distributions. With adjustment

Table 1 Age and sTGF $\beta r I I I$ plasma concentrations in included women. Data are median (quartiles; range) or mean \pm SD (range)

\begin{tabular}{|c|c|c|c|c|c|}
\hline & \multicolumn{2}{|c|}{ Women without breast carcinoma } & \multicolumn{3}{|c|}{ Women with breast carcinoma } \\
\hline & Healthy women & Benign lesions & All & AJCC stage $0-I$ & AJCC stage IIA-B \\
\hline N & 158 & 65 & 147 & 93 & 54 \\
\hline Age (years) & $41(37-56 ; 19-87)$ & $42(35-48 ; 18-72)$ & $63(50-69 ; 20-86)$ & $63(50-70 ; 31-79)$ & $63(50-69 ; 29-86)$ \\
\hline sTGFßrlll (ng/mL) & $97 \pm 33(29-215)$ & $85 \pm 28(32-153)$ & $111 \pm 31(6.3-230)$ & $110 \pm 33(6.3-230)$ & $113 \pm 27(52-190)$ \\
\hline
\end{tabular}

AJCC American Joint Committee on Cancer

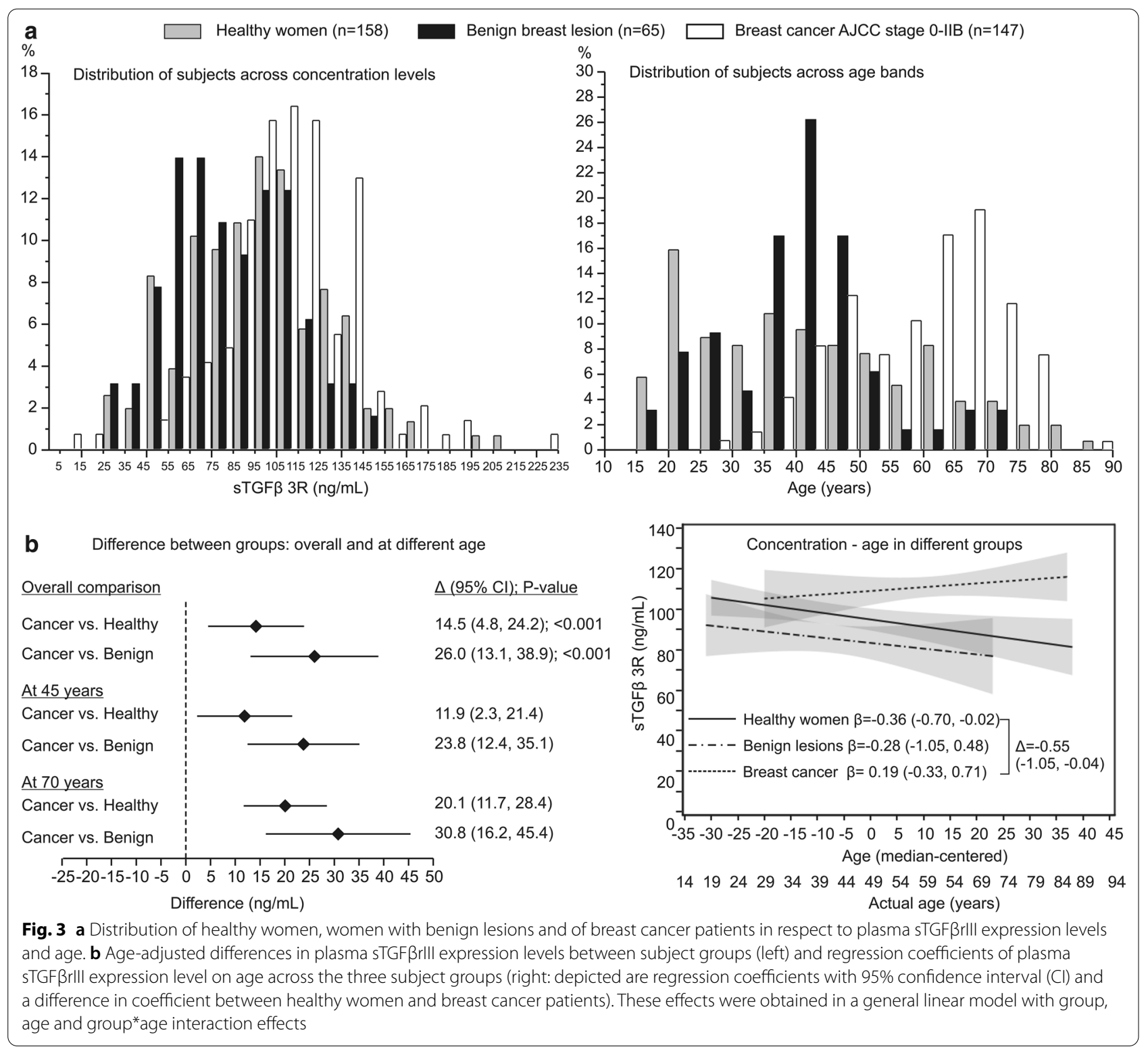


for age, sTGF $\beta$ rIII plasma concentrations were higher in women with breast cancer than in healthy women (by around $14.5 \mathrm{ng} / \mathrm{mL}$ ) and in women with benign lesions (by around $26 \mathrm{ng} / \mathrm{mL}$ ) (Fig. 3b) with a tendency of larger differences at higher age (Fig. 3b); conversely, in healthy women and women with benign lesions, concentrations tended to decrease with older age, but no such trend was apparent in women with breast cancer (Fig. 3b).

\section{Plasma sTGF $\beta r l l l$ levels in women with breast cancer after surgery}

Of the 147 women with AJCC stage 0-IIB breast carcinoma, all with pre-surgery determined sTGF $\beta r I I I$ levels, 120 provided blood samples at 10-30 days after surgery and 81 provided the samples at all three time points. "Completers" ( $\mathrm{n}=81)$ were comparable to "non-completers" $(n=66)$ in respect to age [median 63 (range 31-79) years vs. median 62 (range 29-86) years] and AJCC stages $(67.9 \%$ stage 0 -I vs. $57.6 \%$ stage 0 -I and
42.4\% stage IIA-IIB). Individual data for all women and for the subset of "completers" indicated a trend towards reduction of sTGF $\beta$ rIII concentrations over time (Fig. 4). With adjustment for age, AJCC stage and time*age interaction, differences between 10 and 30 days after surgery and values before surgery were minor in both patient subsets, but values at 160-180 days after surgery were clearly lower (by around 23-26 ng/mL) vs. the values before surgery (Fig. 4). Moreover, there appeared to be no association between age and plasma sTGFßrIII concentration at 10-30 days after surgery (i.e., the coefficients were similar to those observed before surgery), while at 160-180 days after surgery, there was a tendency of lower concentrations with older age (Fig. 4), just as observed in healthy women (Fig. 3). None of the women died or experienced disease recurrence during the observed period, and none died over a period of up to 3 years (last patient's last sample) since the recruitment of the first patient.
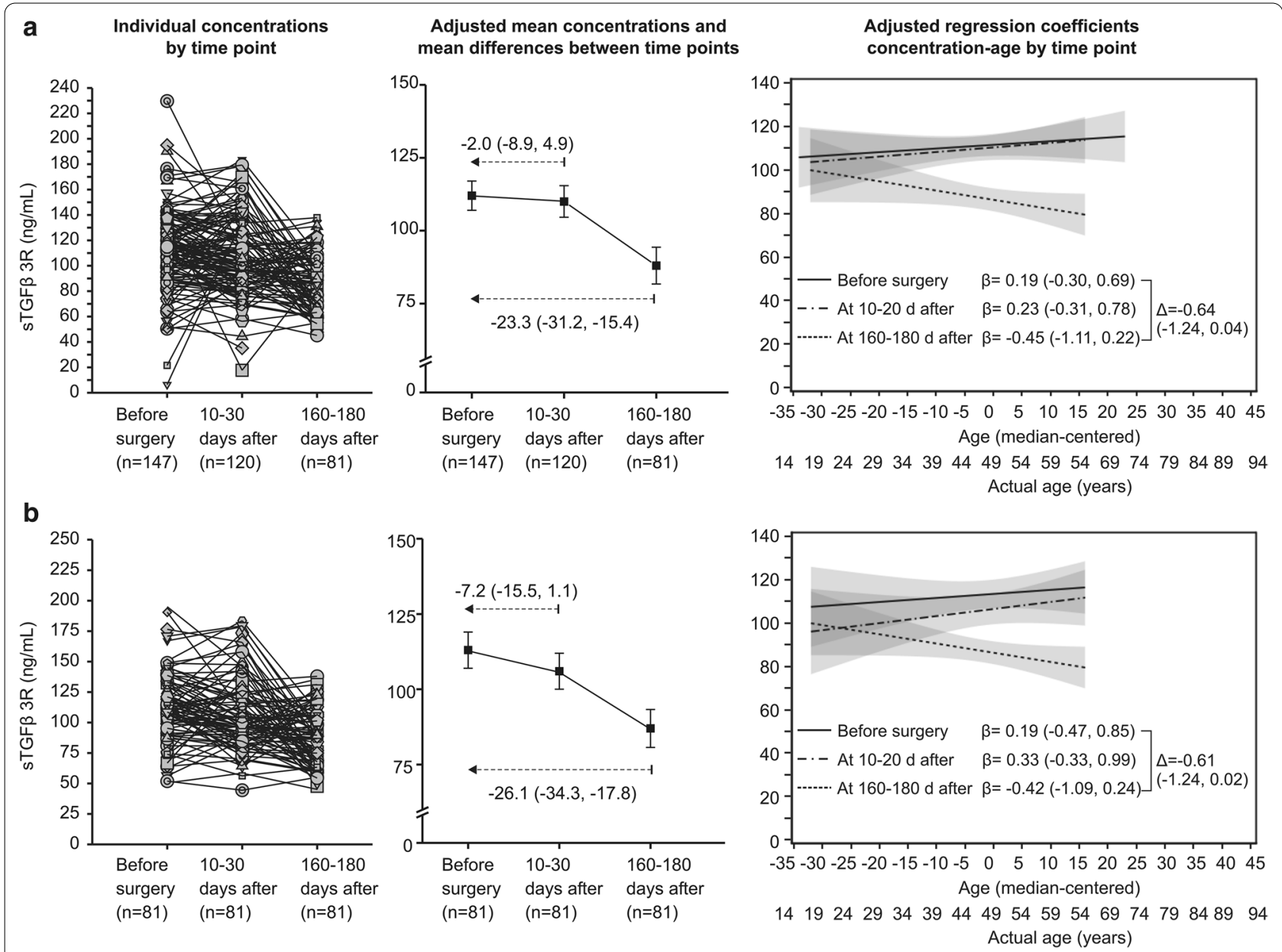

Fig. 4 Plasma sTGFßrlll expression levels in breast cancer patients over time. a All available data. b Data for 81 patients that contributed blood samples at all time-points 


\section{TGF $\beta$ rlll expression in breast cancer tissue}

Prior to IHC staining, all hematoxylin-eosin-stained slides were examined to determine a sample that, in addition to the tumor/benign lesion, contained normal breast tissue as an internal control. Breast ducts and lobules in benign lesions showed clear expression of TGFßrIII, which was strongest on the membranes of epithelial and especially in myoepithelial cells. TGFßrIII expression was strong in 2, moderate in 6 , and weak in 2 patients (Fig. 5 b, c).

TGFßrIII was not detected in 6 of the analyzed malignant cases and 4 showed a weak, albeit detectable membrane staining (Fig. 5e, f). A single case had moderate to strong membrane expression, and a patient with lobular invasive carcinoma had a mild cytoplasmic TGFßrIII staining. Distribution of TGF $\beta$ rIII scores and staining index values for patients with breast carcinoma or benign breast lesions is shown in Fig. 6.

\section{Discussion}

The multifunctional TGFß pathway affects the disease course of breast cancer patients, so it is important to understand the fine mechanisms of its regulation [18]. When TGFß binds to its receptors (TGFßrI and II), their activation seems to be dependent on a Type III coreceptor membrane-bound molecule. This co-receptor can nevertheless be rapidly cleaved and released into extracellular space, thus competing for available TGFß

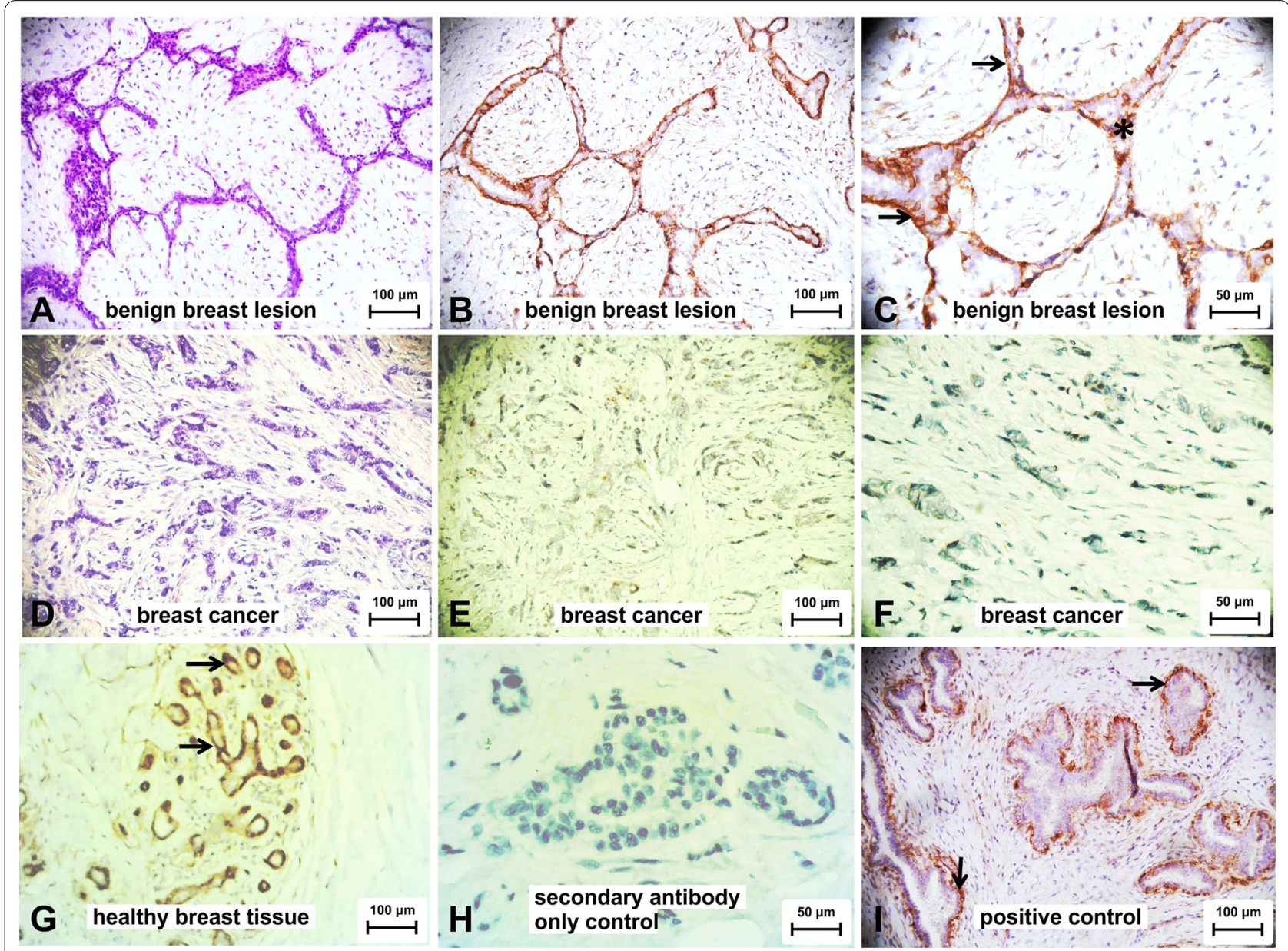

Fig. 5 Loss of TGFBrlll protein in breast cancer. TGFBrlll expression was analyzed by immunohistochemistry (IHC) using anti TGFBrlll (sc-74511) and chromogenic detection. $\mathrm{IHC}$ staining was scored on a 0 to 3 scale by a board-certified pathologist, 0 corresponding to no staining and 3 to high staining levels. H\&E staining of benign breast tissue lesion (a) and breast cancer (d). Representative staining of TGF $\beta r l l l$ in a benign breast lesion (b, 20x; c 40x), with positive epithelial (asterisk) and myoepithelial cells (arrows). Similar results were obtained in healthy breast tissue, obtained as an

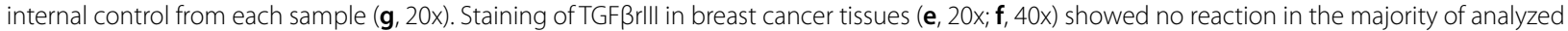
samples. Secondary antibody only control (h); positive tissue control, benign breast tissue lesion (i). Note the significant decrease in staining intensity in breast cancer $(\mathbf{e}, \mathbf{f})$ in comparison to healthy tissues $(\mathbf{g})$ and benign lesion of breast tissue $(\mathbf{b}, \mathbf{c})$ 

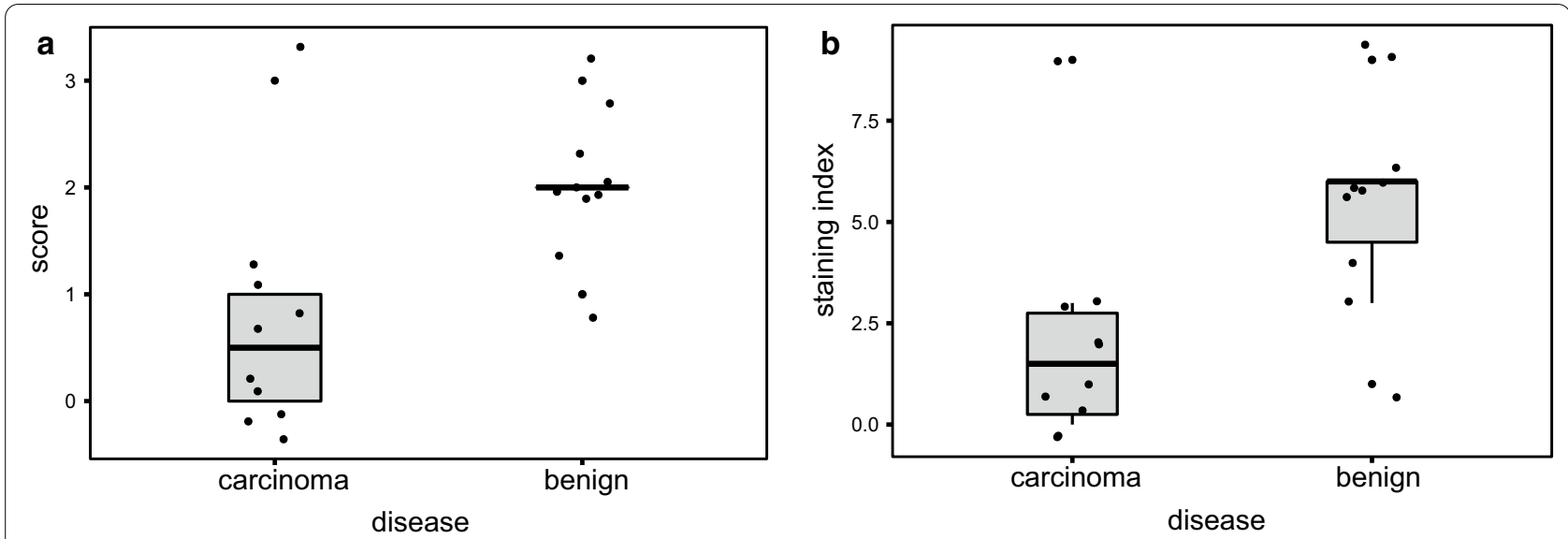

Fig. 6 TGFßrlll immunohistochemistry quantification results: scores (a) and staining indices (b). Dots are individual values, horizontal lines depict medians, boxes are quartiles and bars are inner fences

molecules and leaving the receptors "empty handed". It was previously shown that dysregulation of TGFßrIII is an early event in breast cancer development, however this co-receptor can also have an anti-tumor effect [12]. The crucial event is the solubilization (release) of the membrane form, which competes for TGF $\beta$ ligands, and thus inhibits TGF $\beta$-mediated tumor progression [16]. The ratio of membrane bound vs. soluble form of this co-receptor was also shown to regulate activity of other important breast cancer mediators, like the BMP-family proteins [19]. Therefore, TGFßrIII can exert different downstream effects depending on its expression levels and cellular localization.

We previously conducted a small-sample study that revealed an increase in plasma sTGFßrIII levels in earlystage breast carcinoma patients two months post breast cancer surgery [7]. Different research groups have since published contradictory results, which prompted a further investigation with a larger number of patients using a validated commercial ELISA kit and extensive controls to exclude possible physiologic oscillations of sTGFßRIII, unrelated to the disease $[6,19]$. It is well known that cytokine production can be influenced by sex hormones and diurnal variation. We have thus excluded their influence on plasma sTGFßrIII in a preliminary study, by sampling patients at different menstrual-cycle time points and different times of day. In the main study, plasma levels of sTGF $\beta$ rIII in breast cancer patients were monitored before and after surgery and compared to benign breast lesions and healthy controls. Furthermore, we analyzed the tissue expression of TGFßrIII in samples of randomly selected women with breast cancer and benign breast disease in order to correlate circulating to membrane-bound co-receptor levels. In contrast to the pilot study, our repeated results were in line with several other reports, which can be accounted for by the use of optimized detection antibodies and a larger sample size. Present data suggest two potentially important conclusions: i) plasma levels of sTGFßrIII do not seem to be dependent on menstrual cycle or diurnal variations; ii) reduced TGF $\beta$ rIII expression in breast cancer tissue could result from ectodomain shedding.

The present data indicate higher plasma sTGFßrIII levels in (early-stage) breast cancer patients than in healthy women and women with benign breast lesions (which, in turn, are comparable to each other in this respect). The observed differences appeared greatest in women over 50 years of age. At $160-180$ days after surgery, i.e., tumor mass removal, plasma levels of sTGFßrIII declined towards values seen in healthy women. Another indicator of "normalization" (post-tumor removal) is the regain of the association between older age and lower sTGFßrIII levels seen in healthy women, but not in breast cancer patients before surgery. Breast cancer screening programs mostly target postmenopausal women, since the worldwide disease incidence peaks around the age of 60 , with a sharp incline beginning at 40 years of age [20, 21]. Therefore, the use of sTGF $\beta r I I I$ as a potential early plasma biomarker of breast cancer should be further explored. As breast cancer patients tend to be of older age, this assay could potentially complement mammography screenings and help discern diagnostically problematic lesions in postmenopausal women. It also seems feasible to extend the research to evaluate whether longterm follow-up with occasional measurements of plasma sTGFßrIII levels could be used for early detection of disease relapse.

However, it is always a challenge to distinguish metabolic events that are pathologically significant from ones that are a mere protein turnover mechanism, unrelated 
to carcinogenesis. The role of TGFßrIII in this spectrum still needs to be clarified: is it part of an anti-cancer mechanism that averts TGFß-related carcinogenesis or a consequence of the disease that can nevertheless be used as an indicator of disease occurrence, progression, or the efficacy of therapeutic interventions.

The origin of plasma sTGFßrIII is under debate. In complex tumor environments numerous soluble and membrane bound proteases (sheddases) can release a broad array of substrates into circulation [23]. In 2019, Huang et al. suggested that fibroblasts, immune and endothelial cells from the tumor environment could be the source of plasma sTGFßrIII [6]. The present data support such a view, as we observed a significant drop in plasma sTGFßrIII levels when the tumor tissue was surgically removed. Moreover, IHC findings revealed that lower tissue TGF $\beta r I I I$ expression levels in breast cancer patients than in healthy women and patients with benign breast changes. Since sTGF $\beta$ RIII is readily detectable in plasma of healthy people and in patients with benign breast changes, we can assume that the co-receptor is continuously released at low levels. The reduction of TGFßrIII tissue expression was confirmed in most human cancers, and was also correlated to disease progression and prognosis [17-19, 23-25]. This simultaneous exchange seems to result from ectodomain shedding that releases soluble receptor forms from tissues into circulation. This process is closely related to the etiology of malignant disease and could be a physiologic response used to neutralize the effects of TGF $\beta$ molecules on tumor cell invasion, motility and migration [12, 26] (Fig. 7).

The present study is limited by still a modest sample of patients recruited at a single center and inclusion of only early-stage patients (AJCC 0-IIB) with favorable outcomes. The latter was a planned decision as it enabled an insight into sTGFßrIII levels before and after a (presumably) total tumor mass removal. A further limitation is a rather high drop-out of patients at repeated post-surgery blood samplings (patients chose not to participate). However, a similar trend was observed when all available data at each time-point were considered and when only "completers" were considered. Furthermore, the two subsets ("completers" and "drop-outs") appeared similar in age and AJCC stage. Finally, the follow-up period (3 years for clinical outcomes and 6 months for plasma concentrations) was also limited, but it detected a trend

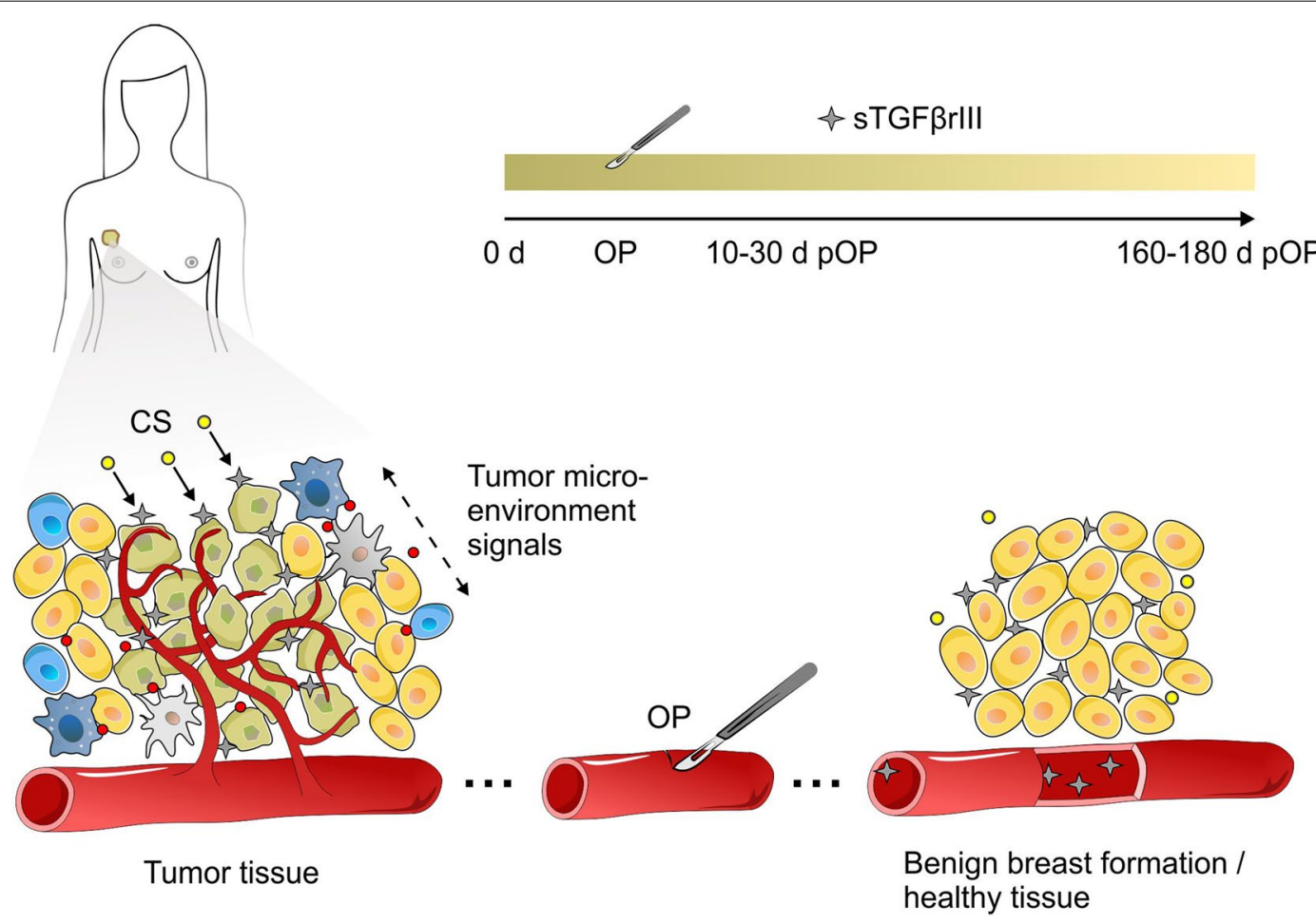

Fig. 7 Proposed scheme for tumor microenvironment influence on TGFßrlll shedding from cell surface and modulation of its concentration in bodily fluids. Tumor cells recruit stromal, immune and vascular cells by secreting stimulatory growth factors, chemokines and cytokines. These cells release growth-promoting signals, which have a role in remodeling of tumor structure microenvironment and catalytic sheddases (CS) activity. This results in increased release of STGFBrlll to the surrounding tissue and bodily fluids. After surgical tumor removal and the stabilization of the tissue CS activity (4-6 months), sTGF $\beta$ rlll levels are normalized to a level found in healthy and benign breast formations 
that justifies a larger study focused on postmenopausal women. This (sub)population is at the highest risk from this disease, and it is suitable to further evaluate the usability of plasma sTGF $\beta$ RIII as a potential complementary tool in breast cancer diagnosis and disease monitoring.

\section{Conclusions}

In this prospective study we found that plasma sTGFßrIII levels in newly diagnosed early-stage (AJCC 0-IIB) breast cancer patients are higher than in healthy women or women with benign breast lesions. These findings are in correlation with lower tissue expression of TGFßrIII in malignant lesions vs. healthy breast tissue and implicate ectodomain shedding as a possible source of circulating sTGFßrIII. Furthermore, the difference between cancer and non-cancer participants appears to be greater in women over 50 years of age: we observed that in the noncancer participants (but not in cancer patients) sTGFßrIII levels decline with age. Moreover, after surgical tumor removal, plasma sTGFßrIII levels decline towards levels seen in healthy women, and the association between older age and lower levels is thus re-gained. Additionally, plasma sTGFßrIII levels do not appear to change significantly throughout the ovarian cycle or time of day.

\begin{abstract}
Abbreviations
ADAM: Disintegrin and metalloproteinase domain-containing protein; AJCC: American Joint Committee on Cancer; BMP: Bone morphogenetic protein; $\mathrm{Cl}$ : Confidence interval; CS: Catalytic sheddase; CV: Coefficient of variation; EGF: Epidermal growth factor; ELISA: Enzyme linked immunosorbent assay; FGF: Fibroblast growth factor; FISH: Fluorescence in situ; GMR: Geometric means ratio; HER2: Human epidermal growth factor receptor 2; HRP: Horseradish peroxidase; IHC: Immunohistochemistry; SD: Standard deviation; sTGFßrlll: Soluble type III transforming growth factor receptor; TGF $\beta$ : Transforming growth factor $\beta ;$ TGF $\beta$ rIII:Type III transforming growth factor receptor.
\end{abstract}

\section{Acknowledgements}

We thank all participating patients and acknowledge the staff at University Hospital Centre Sestre milosrdnice Ljiljana Mayer, Luka Bender and medical student Laura Mayer for their help in sample preparation and technical advice.

\section{Authors' contributions}

LG, RN, VT, SH, GS, JB, LFH, IM, TV, MPB, KB all made substantial contributions to the conception or design of the work, the acquisition, analysis, revision or interpretation of data for the work. LG conceptualization ideas, analysis, writing original draft, investigation supervision; RN investigation, formal analysis, data curation, writing original draft, project administration; VT writing and editing preparation, data curation management activities; SH, GS, JB formal analysis, investigation, writing original draft; LFH methodology, formal analysis; IM investigation supervision, editing preparation, data curation; TV and KB methodology, sample collection; MPB methodology, editing preparation. All authors read and approved the final manuscript.

\section{Funding}

This work was funded by the Adris project Foundation knowledge and discovery for the project: New markers for the detection and monitoring of breast tumors - BIOBREAST and the Scientific Center of Excellence for Reproductive and Regenerative Medicine (project "Reproductive and regenerative medicine - exploration of new platforms and potentials", Grant Agreement KK01.1.1.01.0008) which is funded by the European Union through the European Regional Development Fund.
Availability of data and materials

Study data is available upon reasonable request.

\section{Ethics approval and consent to participate}

This prospective observational study was approved by the Ethics Committee of the University Hospital Center Sestre milosrdnice (EP-1402/18-3). All participants provided a signed informed consent.

\section{Consent for publication}

Not applicable.

\section{Competing interest}

The authors declare that they have no competing interests.

\section{Author details}

${ }^{1}$ Center for Translational and Clinical Research, Department of Proteomics, School of Medicine, University of Zagreb, Zagreb, Croatia. ${ }^{2}$ Department of Anatomy, Drago Perovic, School of Medicine, University of Zagreb, Drago Perovic, Zagreb, Croatia. ${ }^{3}$ Department of Pharmacology, School of Medicine, University of Zagreb, Zagreb, Croatia. ${ }^{4}$ University Hospital for Tumors, University Hospital Center Sestre Milosrdnice, Zagreb, Croatia. ${ }^{5}$ Center for Proteomics, Center for Translational and Clinical Research, School of Medicine, University of Zagreb, Salata 11, Zagreb, Croatia.

Received: 21 September 2020 Accepted: 3 December 2020

Published online: 11 December 2020

\section{References}

1. Chen X-H, Li X-Q, Chen Y, Feng Y-M. Risk of aggressive breast cancer in women of Han nationality carrying TGFB1 rs1982073 C allele and FGFR2 rs1219648 G allele in North China. Breast Cancer Res Treat. 2011;125(2):575-82.

2. O. Alanazi I, Khan Z. Endocrine and Cell Surface Receptor Signaling in Breast Carcinogenesis. Breast Cancer Surg. 2018;.

3. Kumar R, Panwar D, Amirtham U, Premalata C, Gopal C, Narayana S, et al. Estrogen receptor, Progesterone receptor, and human epidermal growth factor receptor-2 status in breast cancer: A retrospective study of 5436 women from a regional cancer center in South India. South Asian J Cancer [Internet]. 2018 Jan 1;7(1):7-10. Available from: http://journal.sajc. org/article.asp?issn $=2278-330 X$.

4. Thery L, Meddis A, Cabel L, Proudhon C, Latouche A, Pierga J-Y, et al. Circulating Tumor Cells in Early Breast Cancer. JNCI cancer Spectr. 2019 Jun;3(2):pkz026.

5. Ivars Rubio A, Yufera JC, de la Morena P, Fernández Sánchez A, Navarro Manzano E, García Garre E, et al. Neutrophil-lymphocyte ratio in metastatic breast cancer is not an independent predictor of survival, but depends on other variables. Sci Rep. 2019;9(1):16979.

6. Huang JJ, Corona AL, Dunn BP, Cai EM, Prakken JN, Blobe GC. Increased type III TGF- $\beta$ receptor shedding decreases tumorigenesis through induction of epithelial-to-mesenchymal transition. Oncogene [Internet]. 2019 May 14;38(18):3402-14. Available from: http://www.nature.com/articles/ s41388-018-0672-7.

7. Jurisic D, Erjavec I, Trkulja V, Dumic-Cule I, Hadzibegovic I, Kovacevic L, et al. Soluble type III TGF $\beta$ receptor in diagnosis and follow-up of patients with breast cancer. Growth Factors. 2015;33(3):200-9.

8. Roberts $A B$, Wakefield $L M$. The two faces of transforming growth factor $\beta$ in carcinogenesis. Proc Natl Acad Sci U S A. 2003;100(15):8621-3.

9. Gatza CE, Oh SY, Blobe GC. Roles for the type III TGF- $\beta$ receptor in human cancer. Cell Signal. 2010;22(8):1163-74.

10. Liu S, Chen S, Zeng J. TGF- $\beta$ signaling: a complex role in tumorigenesis (Review). Mol Med Rep. 2018;17(1):699-704.

11. Jenkins $L M$, Horst $B$, Lancaster $C L$, Mythreye K. Dually modified transmembrane proteoglycans in development and disease. Cytokine Growth Factor Rev [Internet]. 2018;39(December):124-36. http://dx.doi. org/10.1016/j.cytogfr.2017.12.003.

12. Dong M, How T, Kirkbride KC, Gordon KJ, Lee JD, Hempel N, et al. The type III TGF- $\beta$ receptor suppresses breast cancer progression. J Clin Invest. 2007;117(1):206-17 
13. Elderbroom JL, Huang JJ, Gatza CE, Chen J, How T, Starr M, et al. Ectodomain shedding of TRRIII is required for TBRIII-mediated suppression of TGF- $\beta$ signaling and breast cancer migration and invasion. Mol Biol Cell. 2014;25(16):2320-32.

14. Hanks BA, Holtzhausen A, Evans KS, Jamieson R, Gimpel P, Campbell OM, et al. Type III TGF- $\beta$ receptor downregulation generates an immunotolerant tumor microenvironment. J Clin Invest [Internet]. 2013/08/08. 2013 Sep;123(9):3925-40. https://pubmed.ncbi.nlm.nih.gov/23925295.

15. Bandyopadhyay A, Zhu Y, Cibull ML, Bao LW, Chen C, Sun LZ. A soluble transforming growth factor $\beta$ type III receptor suppresses tumorigenicity and metastasis of human breast cancer MDA-MB-231 cells. Cancer Res. 1999;59(19):5041-6.

16. Bandyopadhyay A, López-Casillas F, Malik SN, Montiel JL, Mendoza V, Yang $J$, et al. Antitumor activity of a recombinant soluble betaglycan in human breast cancer xenograft. Cancer Res. 2002;62(16):4690-5.

17. Xie F, Ling L, Van Dam H, Zhou F, Zhang L. TGF- $\beta$ signaling in cancer metastasis. Acta Biochim Biophys Sin. 2018:50(1):121-32.

18. Zarzynska JM. Two faces of TGF-beta1 in breast cancer. Mediators Inflamm [Internet]. 2014/05/07. 2014;2014:141747. Available from: https ://pubmed.ncbi.nlm.nih.gov/24891760.

19. Gatza CE, Elderbroom JL, Oh SY, Starr MD, Nixon AB, Blobe GC. The Balance of Cell Surface and Soluble Type III TGF- $\beta$ Receptor Regulates BMP Signaling in Normal and Cancerous Mammary Epithelial Cells. Neoplasia [Internet]. 2014;16(6):489-500. http://dx.doi.org/10.1016/j. neo.2014.05.008

20. Jovanović B, Pickup MW, Chytil A, Gorska AE, Johnson KC, Moses HL, et al. TRRIII expression in human breast cancer stroma and the role of soluble TRRIII in breast cancer associated fibroblasts. Cancers. 2016;8(11):1-18.
21. Winters S, Martin C, Murphy D, Breast Shokar NK, Epidemiology Cancer. Prevention, and Screening [Internet]. Vol. 151, Progress in Molecular Biology and Translational Science. Elsevier Inc. Elsevier Inc. 2017. https://doi. org/10.1016/bs.pmbts.2017.07.002.

22. Rojas K, Stuckey A. Breast Cancer Epidemiology and Risk Factors. Clin Obstet Gynecol. 2016;59(4):651-72.

23. Clark P. Protease-mediated ectodomain shedding. Thorax. 2014;69(7):682-4.

24. Hempel N, How T, Dong M, Murphy SK, Fields TA, Blobe GC. Loss of betaglycan expression in ovarian cancer: role in motility and invasion. Cancer Res. 2007;67(11):5231-8.

25. Turley RS, Finger EC, Hempel N, How T, Fields TA, Blobe GC. The type III transforming growth factor- $\beta$ receptor as a novel tumor suppressor gene in prostate cancer. Cancer Res. 2007;67(3):1090-8.

26. Ahn JY, Park S, Yun YS, Song JY. Inhibition of type III TGF- $\beta$ receptor aggravates lung fibrotic process. Biomed Pharmacother [Internet]. 2010;64(7):472-6. Available from: http://dx.doi.org/10.1016/j.bioph a.2010.01.006.

27. Lichtenthaler SF, Lemberg MK, Fluhrer R. Proteolytic ectodomain shedding of membrane proteins in mammals-hardware, concepts, and recent developments. EMBO J. 2018;37(15):1-24.

\section{Publisher's Note}

Springer Nature remains neutral with regard to jurisdictional claims in published maps and institutional affiliations.
Ready to submit your research? Choose BMC and benefit from:

- fast, convenient online submission

- thorough peer review by experienced researchers in your field

- rapid publication on acceptance

- support for research data, including large and complex data types

- gold Open Access which fosters wider collaboration and increased citations

- maximum visibility for your research: over $100 \mathrm{M}$ website views per year

At BMC, research is always in progress.

Learn more biomedcentral.com/submissions 